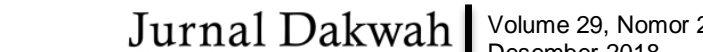 \\ RISALAH Hating \\ P-ISSN: $1412-0348$
E-ISSN: $2654-3877$
}

\section{IMPLEMENTASI SUMBER DAYA MANUSIA PENGELOLA MASJID- MASJID NAHDLIYYIN DI KABUPATEN SIDOARJO (Studi Historis PC LTMNU Sidoarjo Periode 2006-2011)}

\author{
Mohammad Mochtar Mas'od ${ }^{1 *}$, M. Zainuddin ${ }^{2}$ \\ ${ }^{1}$ Sekolah Pascasarjana Universitas Airlangga Surabaya \\ ${ }^{2}$ Program Pascasarjana Institut Agama Islam Al-Khoziny Sidoarjo \\ *E- mail: mohammadmochtarmasod@gmail.com
}

\section{Kata kunci \\ Implementasi, $P C$ LTMNU Sidoarjo, Sumber Daya Manusia Masjid Nahdliyyin}

\begin{abstract}
Abstrak
Masjid merupakan pilar utama dakwah Islam sejak zaman Rosululloh hingga saat ini. Masjid menjadi pusat pengumpulan dan pembedayaan umat. Masjid memiliki beberapa fungsi strategis yakni sebagai pusat sarana ibadah (ubudiyah), pusat pengembangan sosial ekonomi (ijtimaiyah iqtishodiyah), pusat pendidikan dan ilmu (tarbiyah) dan bahkan pusat politik (siyasah). Penelitian ini menggunakan pendekatan kualitatif yang menekankan pada penelitian historis untuk rentang waktu periode kepengurusan 2006-2011. Data diperoleh dari arsip dokumen organisasi, wawancara tokoh dan narasumber yang terkait dan berkompeten, studi pustaka kemasjidan, ketakmiran, ke-NU-an khususnya terkait LTMNU. Temuan yang diperoleh adalah bahwa PC LTMNU dalam mengimplementasikan pendidikan SDM pengelola masjid Nahdliyyin mengacu pada keputusan organisasi. Pendidikan dilaksanakan dalam tiga bentuk yakni diklat, kajian umum tematik dan konsultasi langsung. Diklat yang dilaksanakan merupakan bentuk dari pendidikan berbasis masyarakat yang berangkat dari kebutuhan masyarakat, dilakukan oleh masyarakat dan dengan kemampuan masyarakat.
\end{abstract}

Keywords
Human Resources
of Nahdliyyin
Mosque,
Implementation,
PC LTMNU
Sidoarjo

\begin{abstract}
Mosques have been the main pillars of Islamic da'wah since the days of Rosululloh to the present. The mosque is a center for gathering and building people. Mosques have several strategic functions, namely as the center of worship facilities (ubudiyah), the center of socio-economic development (ijtimaiyah iqtishodiyah), the center of education and science (tarbiyah) and even the political center (siyasah). This study uses a qualitative approach that emphasizes historical research for the period of the management period of 2006-2011. Data was obtained from the archives of organizational documents, interviews with relevant and competent figures and sources, literature studies on mosque, injustice, $N U$ in particular related to LTMNU. The findings obtained were that the LTMNU PC in implementing HR education in the management of the Nahdliyin mosque referred to organizational decisions. Education is carried out in three forms namely training, thematic general study and direct consultation. Diklat implemented is a form of community-based education that departs from the needs of the community, carried out by the community and with the ability of the community.
\end{abstract}




\section{Pendahuluan}

Masjid sejak awal memegang peranan penting dalam kegiatan pendidikan umat. Di masjid sangat mudah mengumpulkan orang. Mereka yang datang ke masjid ingin mendekatkan diri kepada Tuhannya. Di sinilah mereka melepaskan beban himpitan masalah duniawi sehingga mencapai pencerahan rohani. Di masjid pula sebagaimana yang dicontohkan oleh Rasululloh, terjadi proses pendidikan untuk mempersiapkan generasi yang akan datang.

Masjid menurut arti bahasa adalah "tempat sujud". Dalam sebuah hadist dijelaskan bahwa seluruh bumi ini dijadikan masjid (tempat sujud) bagi Nabi Muhammad dan umatnya. Kata (مسجد) masjid terambil dari akar kata (سجود) sujud yang berarti taat, patuh, dan tunduk dengan penuh hormat. Meletakkan dahi kedua telapak tangan dan jari-jari kaki adalah bentuk lahiriyah yang paling nyata dari makna-makna diatas. Dari sini, bangunan yang secara umum digunakan untuk sujud, shalat, dan mengabdi kepada Allah, Tuhan Yang Maha Esa, dinamakan masjid. Di Indonesia masjid diartikan sebagai bangunan tempat ibadah umat Islam yang dipergunakan untuk sholat rawatib (lima waktu) dan sholat Jum'at.

Dari akar katanya, dipahami bahwa masjid bukan hanya berfungsi sebagai tempat meletakkan dahi, yakni sujud dalam shalat, tetapi adalah tempat melakukan aktivitas yang mengandung makna kepatuhan kepada Allah SWT, atau paling tidak tempat mendorong lahirnya aktivitas yang menghasilkan kepatuhan kepada-Nya. Nabi Muhammad SAW bersabda : "Telah dijadikan untukku dan umatku seluruh persada bumi sebagai masjid dan sarana penyucian" (HR. Bukhori Muslim dari Jabir bin Abdullah).

Masjid Nabawi di Madinah memiliki tidak kurang dari sepuluh fungsi. Ia berperan sebagai tempat : a) shalat dan dzikir, b) pendidikan, c) santunan sosial, d) konsultasi dan komunikasi ekonomi, sosial, dan budaya, e) latihan militer, f) pusat kesehatan, g) pengadilan dan penyelesaian sengketa, h) pusat penerangan, i) tahanan, j) tempat penampungan. Semua diarahkan sesuai dengan keberadaan masjid/ bumi sebagai tempat sujud kepada Allah dalam pengertian yang luas.

Di Indonesia juga memiliki kecenderungan yang sama dengan menjadikan masjid sebagai pusat kegiatan selain ibadah Mahdloh. Banyak sekolah atau madrasah, balai kesehatan, pusat pelatihan guru Al-Qur'an, Lembaga Amil Zakat Infaq dan Shodaqoh, TPQ, dan berbagai kursus dan pelatihan yang diselenggarakan oleh masjid. Kompleksitas fungsi masjid disamping fungsi utamanya, menuntut kesiapan sumber daya manusia pengelolanya. Tidak heran Nahdlatul Ulama (NU) sebagai organisasi kemasyarakatan (ormas) Islam terbesar di Indonesia, menjadikan masjid sebagai salah satu dari dua pilar eksistensi dan basis perjuangan. Perhatian NU diwujudkan dengan membentuk Lembaga Takmir Masjid Indonesia (LTMI) yang khusus menangani pemberdayaan masjid Nahdliyyin (sebutan untuk warga NU).

Lembaga Takmir Masjid Indonesia berdasarkan Anggaran Dasar dan Anggaran Rumah Tangga Nahdlatul Ulama hasil mu'tamar NU di Makassar 2010 berganti nama 
menjadi Lembaga Takmir Masjid Nahdlatul Ulama' (LTMNU). Lembaga ini memiliki struktur mulai pusat hingga ranting. LTMNU menjadi ujung tombak pemberdayaan masjid agar bisa melaksanakan peran dan fungsinya dengan baik. Pemberdayaan masjid dimulai dengan pembinaan sumber daya manusia (SDM) pengelolanya. Menyadari hal ini, Pengurus Cabang LTMNU (PC LTMNU) Kabupaten Sidoarjo menyusun serangkaian program pembinaan peningkatan kualitas SDM pengelola masjid di Kabupaten Sidoarjo.

Oleh Pengurus Pusat LTMNU, PC LTMNU Sidoarjo dianggap berhasil dalam pelaksanaan programnya. Beberapa kali PCNU Sidoarjo melalui PC LTMNU mendapat penghargaan dan penghormatan. Terakhir pada tanggal 17 Desember 2011 ketua PC LTMNU menerima penghargaan dari Ketua Umum PBNU atas keberhasilannya.

Dalam usahanya untuk mendidik dan membina SDM pengelola masjid Nahdliyyin, PC LTMI Sidoarjo menyiapkan berbagai perangkat mulai kurikulum, pemateri, media belajar hingga evaluasi dan tanda kelulusan. Temuan awal menunjukkan bahwa paling tidak ada empat cara pembinaan SDM Masjid Nahdliyyin yaitu:

1. Pelatihan, meliputi: pelatihan khothib, pelatihan imam dan makmum, pelatihan bilal muadzdzin dan pelatihan manajemen ketakmiran.

2. Fasilitasi, maksudnya menyediakan tenaga layanan kegiatan masjid meliputi: penyediaan tenaga khothib, bilal, muadzdzin, seleksi imam dan pengisi pengajian rutin.

3. Konsultasi, takmir masjid atau warga Nahdliyyin pada umumnya sering silaturahmi ke PC LTMI Sidoarjo untuk menanyakan persoalan-persoalan yang terkait kemasjidan dan kemasyarakatan.

4. Advokasi. PC LTMI mengupayakan terpenuhinya azas legal formal organisasi ketakmiran dan aset masjid. Upaya yang dilakukan adalah dengan pemberian SK Kepengurusan Takmir dan sertifikasi tanah wakaf masjid.

Penelitian ini bertujuan untuk menemukan jawaban dari pertanyaan mendasar: Bagaimana pola pembinaan yang dilakukan oleh Pengurus Cabang Lembaga Takmir Masjid NU Sidoarjo? Apa keistimewaan yang dimiliki sehingga layak diberi penghargaan tingkat nasional? Apa latar belakang dilakukannya pembinaan dengan pola yang sudah dilaksanakan tersebut?

\section{Metode}

Penelitian ini menggunakan metode kualitatif dengan pendekatan historis yang dimaksudkan untuk merekonstruksi kondisi masa lampau secara objektif, sitematis, dan akurat. Melalui peneltian ini, bukti-bukti dikumpulkan, dievaluasi, dan dianalisis. Selanjutnya berdasarkan bukti-bukti itu dirumuskan simpulan.

Materi yang diteliti adalah kegiatan pembinaan dan pendidikan SDM pengelola masjid Nahdliyyin di Kabupaten Sidoarjo. Materi penelitian diperoleh dari sumber data yang meliputi narasumber dan dokumen yang relevan. Pemilihan narasumber dilakukan 
secara terencana (purposive sampling) dengan metode snow ball. Orientasi teoritik yang digunakan adalah fenomenologi. Teknik pengumpulan data melalui wawancara mendalam, observasi, studi dokumen, penelusuran situs internet, angket, dan diskusi kelompok terfokus. Alat utama penelitian adalah pribadi peneliti didukung dengan perekam audio visual, dokumen foto, dan pencatat data lapangan.

Data yang terkumpul diorganisasi, ditafsirkan, dan dianalisis secara berulang guna penyusunan konsep dan abstraksi temuan lapangan. Teknik analisis menggunakan metode analisis kritis. Kredibilitas data dilakukan dengan metode triangulasi, pengecekan anggota, dan diskusi teman sejawat. Sedangkan dependabilitas dicapai melalui pengauditan oleh pihak yang kompeten dan berwenang.

\section{Hasil dan Pembahasan}

Lembaga Takmir Masjid Nahdlatul Ulama' ( LTMNU) merupakan salah satu dari 14 lembaga yang menjadi pelaksana program Jam'iyah Nahdlatul Ulama'. Pertama kali dibentuk dengan nama HTMI (Haiah Ta'mir Masjid Indonesia) pada 9 Februari 1971 M yang bertepatan dengan tanggal 13 Dzulhijjah $1390 \mathrm{H}$. Pada tahun 2004 melalui keputusan Muktamar NU ke-31 nama HTMI dirubah menjadi LTMI (Lembaga Takmir Masjid Indonesia). Nama terakhir yakni LTMNU diputuskan pada Muktamar NU ke-32 tahun 2010 di Makassar Sulawesi Selatan.

Untuk mengefektifkan pelaksanaan tugas dan amanat dari NU, LTMNU di tingkat pusat (PP LTMNU) menyusun struktur Ketua, Sekretaris dan Bendahara serta beberapa pelaksana yakni: 1) Bidang Penataan Aset dan Perwakafan, 2) Bidang Pembinaan Imam, Bilal dan Muadzin, 3) Bidang Pembinaan Khothib dan Manajemen Masjid, 4) Bidang Kesejahteraan dan Pemberdayaan Ekonomi Umat, dan 5) Bidang Pemuda Remaja Masjid dan Pengembangan SDM masing-masing memiliki lima orang anggota. Dalam melaksanakan tugas dibantu dengan MWC LTMNU di masing-masing kecamatan. Pada beberapa ranting juga dibentuk Pengurus Ranting LTMNU. Semuanya sebagai kepanjangan tangan dan pelaksana program LTMNU.

LTMNU merupakan departementasi dari NU yang melaksanakan tugas bidang pemberdayaan dan pengembangan masjid. Oleh karena itu program yang disusun dan dilaksanakan merupakan terjemahan program NU. Dalam menyusun program kerja, PC LTMNU Sidoarjo menggelar Halaqoh Program Kerja yang menghasilkan program strategis masing-masing bidang. Berikut program yang telah terlaksana.

Tabel 1. Kegiatan LTMNU Kabupaten Sidoarjo 2011-2016

\begin{tabular}{|c|c|c|c|}
\hline NO. & $\begin{array}{l}\text { NAMA } \\
\text { KEGIATAN }\end{array}$ & SUB KERJA & KETERANGAN \\
\hline 1 & $\begin{array}{l}\text { Pendataan } \\
\text { Masjid, Musholla }\end{array}$ & $\begin{array}{lr}\text { Bidang } & \text { Penataan } \\
\text { Aset } & \text { dan }\end{array}$ & $\begin{array}{l}\text { 1. Mulai } 25 \text { Mei 2007, sosialisasi } \\
\text { pentingnya Wakaf Nadhir NU di }\end{array}$ \\
\hline
\end{tabular}




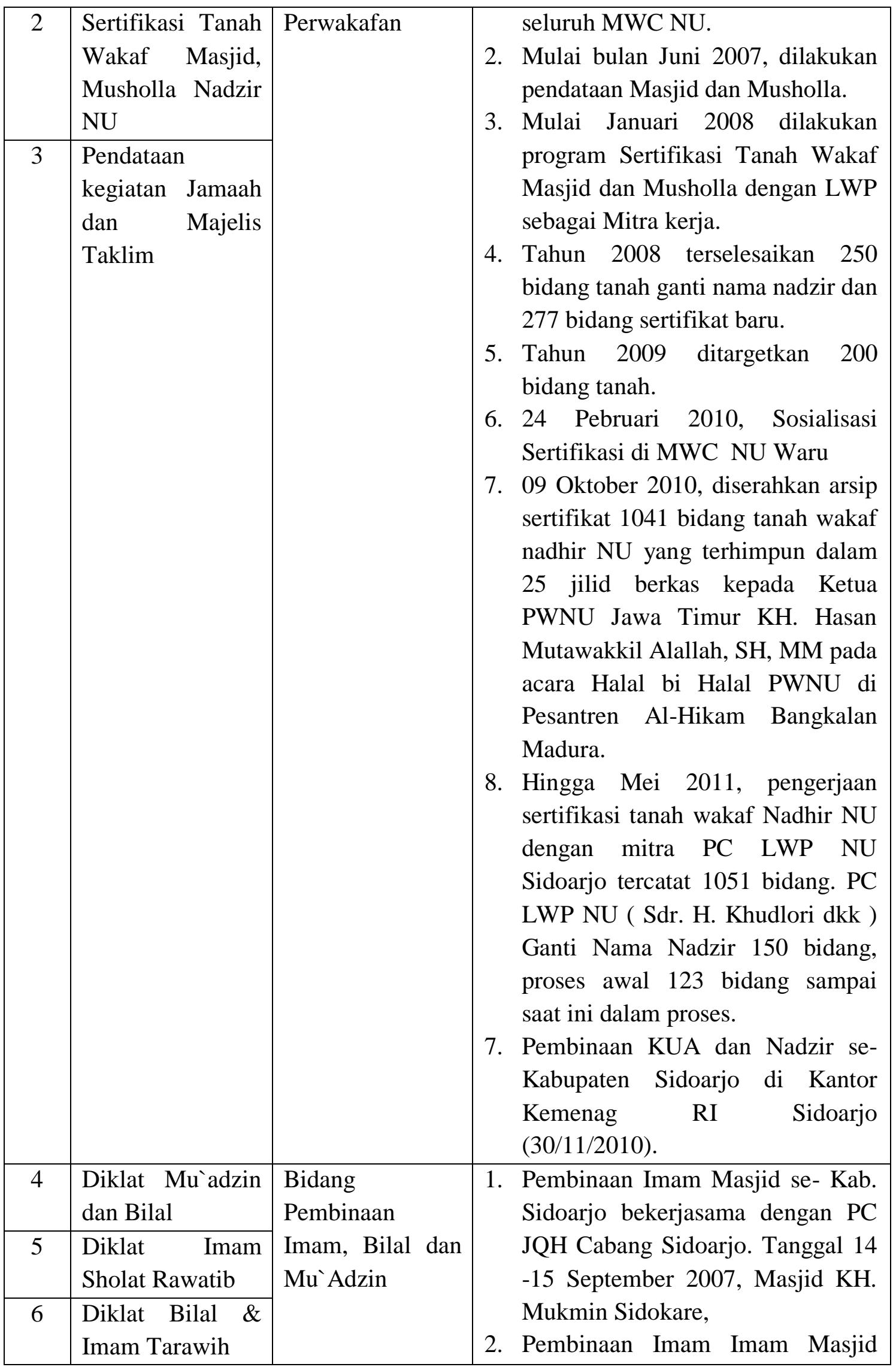




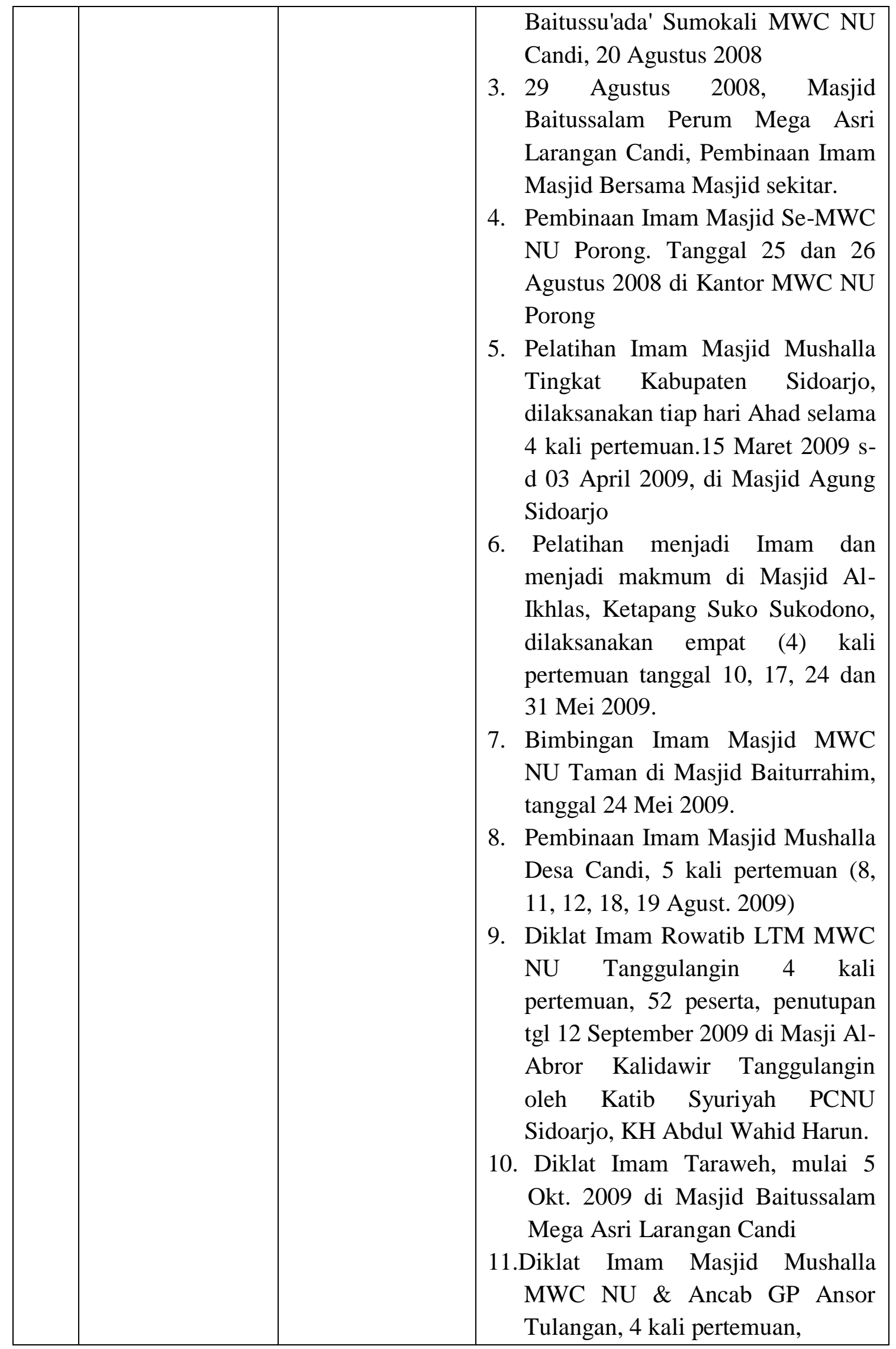




\begin{tabular}{|c|c|c|c|}
\hline & & & $\begin{array}{l}\text { mulai tanggal } 21 \text { Januari } 2010 \text { di } \\
\text { Masjid Roudlotul Jannah } \\
\text { Tulangan. } \\
\text { 12. Pembinaan imam sholat jamaah di } \\
\text { Masjid Al-Abror Sugihwaras } \\
\text { MWC NU Candi (1 s.d } 3 \\
\text { Nopember 2010) } \\
\text { 13. Pembinaan imam di Masjid } \\
\text { Pondok Pesantren Minggir } \\
\text { Larangan MWC NU Candi (4 s.d } 6 \\
\text { Juli 2010) } \\
\text { 14. Pembinaan imam di Masjid Bulang } \\
\text { LTM MWC NU Prambon (27- } \\
\text { 28/11/1010) }\end{array}$ \\
\hline 7 & Diklat Khotib & Bidang & 1. 14 Mei 2007, Kantor MWC NU \\
\hline 8 & $\begin{array}{l}\text { Diklat } \\
\text { Manajemen } \\
\text { Masjid }\end{array}$ & $\begin{array}{l}\text { Pembinaan } \\
\text { Khotib dan } \\
\text { Manajemen }\end{array}$ & $\begin{array}{l}\text { Prambon, Pembinaan Khotib dan } \\
\text { managemen Masjid Se- Kec. } \\
\text { Prambon }\end{array}$ \\
\hline 9 & $\begin{array}{l}\text { Memberdayakan } \\
\text { KAR (Kelompok } \\
\text { Anak Ranting) } \\
\text { NU berbasis - } \\
\text { jamaah Masjid } \\
\text { dan Musholla }\end{array}$ & Masjid & $\begin{array}{l}\text { 2. } 15 \text { Mei 2007, Masjid Ngelom } \\
\text { Taman Pembinaan managemen } \\
\text { Masjid NU. } \\
\text { 3. Mulai } 25 \text { Mei 2007, Pembentukan } \\
\text { Kelompok Anak Ranting (KAR) } \\
\text { NU berbasis Masjid dan Musholla } \\
\text { bersamaan dengan pendataan } \\
\text { Masjid Musholla. Tercatat 5045 } \\
\text { anggota KAR di 218 Masjid dan } \\
\text { 293 musholla. } \\
\text { 49 dan 30 Agustus 2007, di kantor } \\
\text { PCNU Sidoarjo, Pelatihan Khotib / } \\
\text { Da'i Pesisir Kerjasama dengan tim } \\
\text { PEMP dan PC LPNU Sidoarjo } \\
\text { 5. 25 Februari 2008, di Masjid Agung } \\
\text { Sidoarjo, Pemberdayaan Anggota } \\
\text { KAR dengan memantapkan } \\
\text { Aqidah Aswaja An-Nahdliyah } \\
\text { melalui Bedah buku "Aswaja An- } \\
\text { Nahdliyah" dengan nara sumber } \\
\text { Drs.KH. Mashudi Mukhtar, MBA } \\
\text { (Ketua tim Penulis/Sekretaris } \\
\text { PWNU Jatim) }\end{array}$ \\
\hline
\end{tabular}




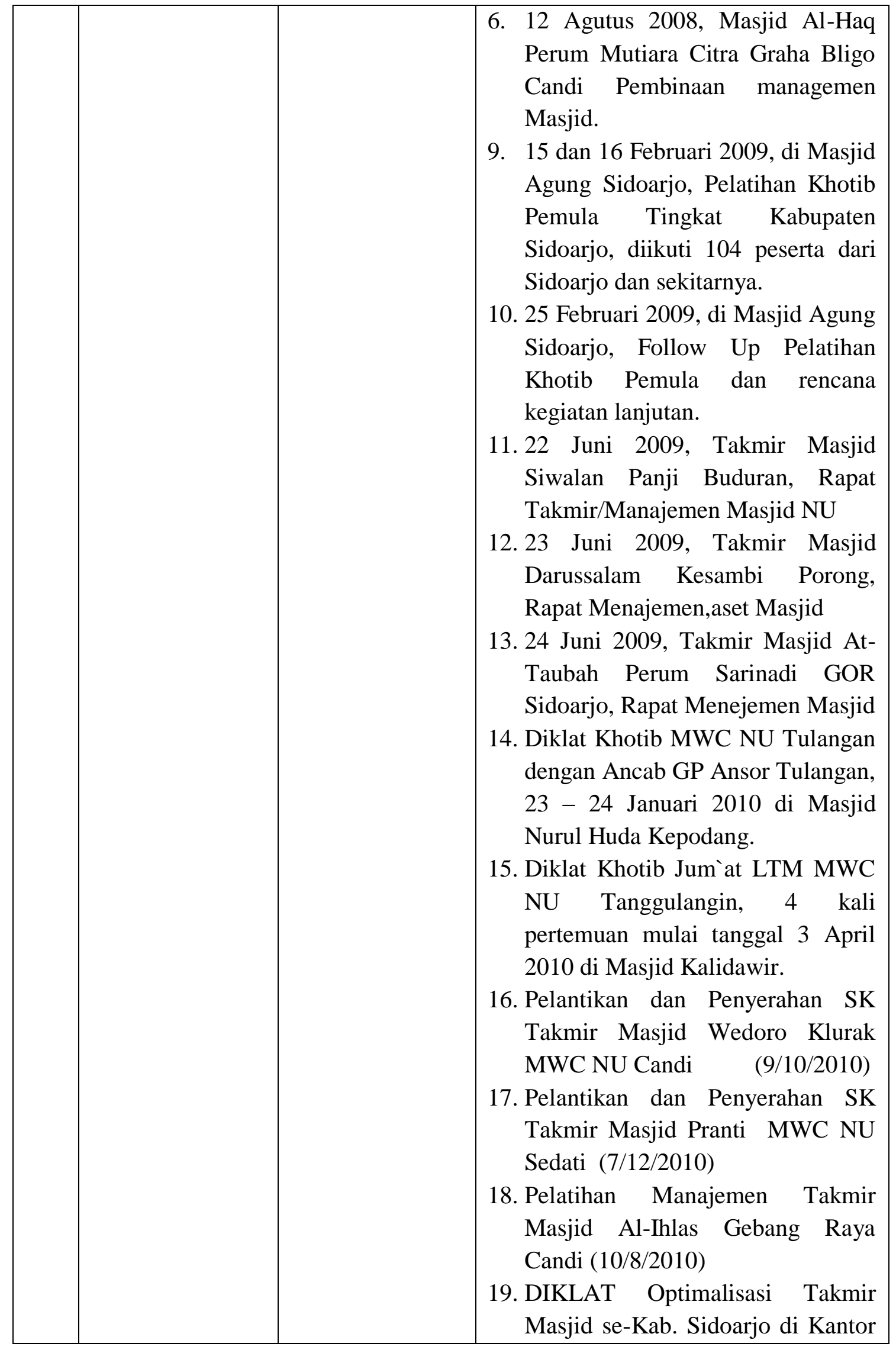




\begin{tabular}{|c|c|c|c|}
\hline & & & $\begin{array}{l}\text { Kemenag RI Kab. Sidoarjo } \\
(22 / 11 / 2010) \\
\text { 20. Pembinaan Takmir di Masjid } \\
\text { Semambung LTM MWC NU } \\
\text { Jabon (12/12/2010) } \\
\text { 21. Pelatihan Khothib jum'at di Masjid } \\
\text { Ponokawan MWC NU Krian (20- } \\
\text { 21/11/2010) } \\
\text { 22. Halaqah Seputar issue Perubahan } \\
\text { arah kiblat kerjasama dengan } \\
\text { Lajnah Falakiyah PCNU } \\
\text { Sidoarjo, dengan narasumber KH. } \\
\text { Ibnu Mas'ud Kholqilla (ketua PW } \\
\text { LTMI NU Jatim) dan KH. } \\
\text { Syafruddin (Katib PWNU Jawa } \\
\text { Timur), 31 Juli 2010 di PCNU } \\
\text { Sidoarjo. } \\
\text { 23. Diklat Khotib Jum at PAC GP } \\
\text { Ansor Porong, 4 kali pertemuan } \\
\text { mulai tanggal 26 Februari 2011 di } \\
\text { kantor MWC NU porong. } \\
\text { 24. Diklat manajemen Takmir masjid } \\
\text { MWC NU Krian, 24-04-2011 di } \\
\text { Masjid Semaji Kemasan Krian. }\end{array}$ \\
\hline 10 & $\begin{array}{l}\text { Membentuk } \\
\text { LAZNU } \\
\text { (Lembaga Amil } \\
\text { Zakat) \& UPZ } \\
\text { NU (Unit } \\
\text { Pengumpul } \\
\text { Zakat) di Masjid } \\
\text { \& Mushalla }\end{array}$ & $\begin{array}{l}\text { Bidang } \\
\text { Kesejahteraan } \\
\text { dan } \\
\text { Pemberdayaan } \\
\text { Ekonomi Umat }\end{array}$ & $\begin{array}{l}\text { 1. Program Jum'at bersih dan renovasi } \\
\text { pengecatan } 2 \text { Masjid dan } 6 \\
\text { Musholla di lingkungan tambak } \\
\text { Kalikajang Gebang MWC NU } \\
\text { Sidoarjo 14 September 2007. } \\
\text { 2. Mengusahakan dana bantuan } 91 \\
\text { proposal Renovasi Masjid ke } \\
\text { DEPAG RI. Tanggal 31 Mei 2008, }\end{array}$ \\
\hline 11 & $\begin{array}{l}\text { Koperasi } \\
\text { Syari`ah, UKM } \\
\text { dan } \\
\text { berbasis } \\
\text { Masjid/Musholla }\end{array}$ & & $\begin{array}{l}\text { di Masjid KH.MUKMIN Sidokare, } \\
\text { Hasilnya } 2 \text { proposal yang di setujui } \\
\text { yakni Masjid Baiturrohim Prambon } \\
\text { dan Masjid Nurul Iman Lemujut } \\
\text { Krembung @ Rp } 50 \text { juta. }\end{array}$ \\
\hline 12 & $\begin{array}{l}\text { Mengusahakan } \\
\text { Bantuan } \\
\text { Renovasi Masjid }\end{array}$ & & $\begin{array}{l}\text { 3. Halaqoh Zakat Dengan nara sumber } \\
\text { Prof.DR. KH. Syechul Hadi } \\
\text { Permono } \\
\text { Hamdan } \quad \text { Wahab,MM dan }\end{array}$ \\
\hline
\end{tabular}




\begin{tabular}{|c|c|c|c|}
\hline & & & $\begin{array}{l}\text { LAZISNU Jatim) Di hadiri Takmir } \\
\text { Masjid se- Kab. Sidoarjo dan } \\
\text { PCNU Sidoarjo.18 Agustus 2008, } \\
\text { di Kantor PCNU } \\
\text { 4. Sosialisai pembentukan Amil Zakat } \\
\text { (LAZIS) di setiap Masjid, 19 } \\
\text { Agustus 2008, di Kantor PCNU } \\
\text { Sidoarjo } \\
\text { 5. Mengikuti Rakor dan Kiswah PW } \\
\text { LAZIS NU Jatim } 2 \text { Mei 2009 di } \\
\text { kantor PWNU Jatim,. } \\
\text { 6. Sosialisasi ukuran 1 Sho' zakat } \\
\text { fitrah dengan mengirim edaran hasil } \\
\text { bahsul masa'il Syuriah PCNU } \\
\text { Sidoarjo.Ramadlan 1429 H. } \\
\text { 7. TURBA PB LTM NU dan } \\
\text { Sosialisasi penggunaan menara } \\
\text { masjid untuk tower operator seluler } \\
\text { bersama PB LBM, 16 Maret 2011 } \\
\text { di kantor PCNU Jl.Erlangga } \\
\text { Sidoarjo. }\end{array}$ \\
\hline 13 & $\begin{array}{l}\text { Membentuk } \\
\text { kepengurusan } \\
\text { Pemuda-Remaja } \\
\text { Masjid NU di } \\
\text { tingkat } \\
\text { Kabupaten, } \\
\text { Kecamatan dan } \\
\text { Desa }\end{array}$ & $\begin{array}{lr}\text { Bidang } & \text { Pemuda } \\
\text { Remaja } & \text { Masjid } \\
\text { dan } & \\
\text { Pengembangan } \\
\text { SDM }\end{array}$ & $\begin{array}{l}\text { 1. Pelantikan Pengurus Pemuda } \\
\text { Remaja Masjid Indonesia PC } \\
\text { LTM NU Sidoarjo.Ahad } 17 \text { Juni } \\
\text { 2007, Masjid Agung Sidoarjo. } \\
\text { 2. Orientasi Kader Nahdliyyin } \\
\text { "Memperkokoh } \\
\text { Ahlussunnah Wal jamaah } \\
\text { Mewaspadai Aliran Radikal Untuk }\end{array}$ \\
\hline 14 & $\begin{array}{lr}\text { Halaqah } \quad \& \\
\text { Kajian } \\
\text { Aswaja } \\
\text { Annahdliyah }\end{array}$ & & $\begin{array}{l}\text { Keutuhan NKRI' nara sumber } \\
\text { DR.KH. Imam Ghozali Said, } \\
\text { MA", } 17 \text { Juni } 2007 \text { di Masjid } \\
\text { Agung Sidoarjo. } \\
\text { 3. Mengikuti Orientasi Problematika } \\
\text { Umat Islam sebagai utusan PCNU } \\
\text { Sidoarjo yang diselenggarakan } \\
\text { oleh DEPAG RI di Asrama Haji } \\
\text { Sukolilo Surabaya tanggal } 17-19 \\
\text { Maret 2008. } \\
\text { Kajian Ilmiah dan Bedah buku } \\
\text { pemberdayaan KAR dan Pemuda }\end{array}$ \\
\hline
\end{tabular}




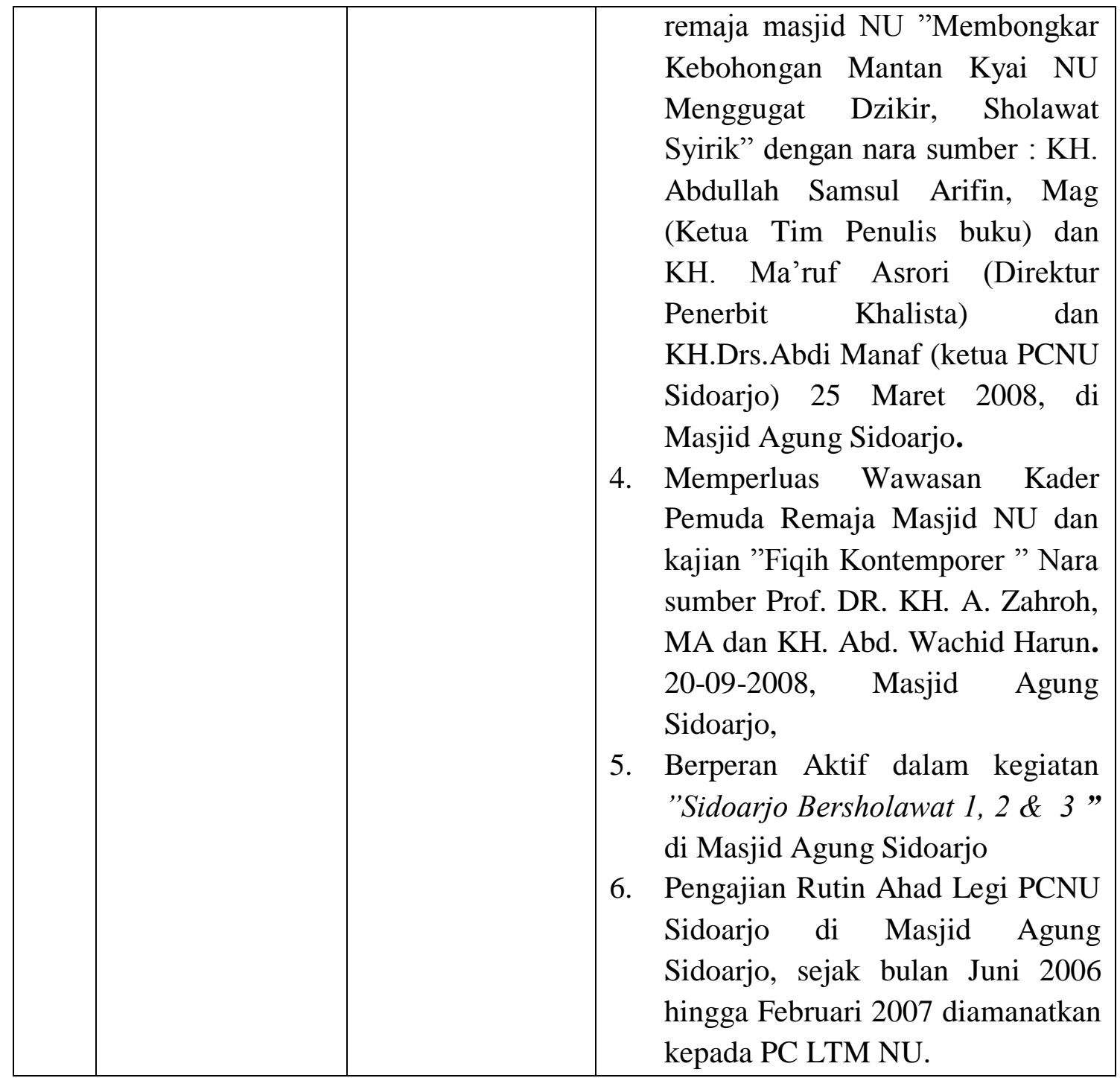

Sumber: Data penelitian

Sumber dana Jam'iyah Nahdlatul Ulama' adalah uang pangkal, i'anah syahriyah, sumbangan, dan usaha lain yang halal dan tidak mengikat. Demikian halnya dengan lembaga di bawah naungan NU termasuk LTMNU. Pada awal kepengurusan PC LTMNU tidak memiliki kas sama sekali. Langkah awal yang ditempuh adalah iuran anggota (urunan) sesuai dengan kemampuan. Secara berangsur, kas organisasi terisi dan digunakan untuk melaksanakan program. Jadi awal menjalankan seluruh aktivitas organisasi adalah dengan dana swadaya.

Masjid Nahdliyyin dibedakan menjadi dua yaitu masjid kultural dan masjid struktural. Masjid kultural adalah masjid yang takmirnya belum disahkan kepengurusannya oleh NU melalui PC LTMNU Sidoarjo. Sedangkan masjid struktural adalah masjid yang takmirnya disahkan oleh NU melalui PC LTMNU. Jumlah masjid strutural masih sedikit. Hingga penelitian ini diujikan masjid struktural berjumlah 57 
masjid. Pembinaan diutamakan pada masjid struktural sebagai basis perjuangan dan pengembangan syiar Islam ahlussunnah wal jamaah annahdlyah.

Penelitian tersebut menunjukkan bahwa SDM adalah hal yang penting dalam penguatan para takmir, kader-kader maupun pemerhati pemberdayaan. Pengembangan SDM memang membutuhkan biaya yang cukup besar, tetapi biaya tersebut merupakan investasi jangka panjang bagi NU. Karena SDM yang cakap dan terampil dapat bekerja lebih efisien, efektif, tidak pemborosan biaya-proses, hasil kerjanya lebih baik, maka kualitas masjid-masjid Nahdliyyin semakin besar. Hal tersebut tentu saja akan memberikan peluang yang lebih baik bagi masjid untuk memperoleh manfaat yang semakin besar, sehingga balas jasa (reward system) para takmir, kader-kader maupun pemerhati pemberdayaan juga wajar ditingkatkan baik berupa finansial maupun status sosialnya.

Sumber daya suatu organisasi terlebih masjid yang sangat penting dan strategis yakni SDM para takmir, kader-kader maupun pemerhati pemberdayaan itu sendiri. Karena tanpa orang-orang yang memiliki keahlian atau kompetensi, maka mustahil bagi organisasi masjid pada penelitian ini mencapai tujuannya. Dalam konteks pencapaian kompetensi para ahli berkeyakinan pengelolaan SDM takmir ditunjang dengan program pelatihan, pendidikan dan pengembangan SDM yang benar. Program pengembangan SDM yang dilakukan PC LTMNU Sidoarjo mengarah pada penguasaan tiga tujuan: 1) Keahlian (skills), 2) Pengetahuan (knowledge), dan 3) Kemampuan (ability).

Implementasi Pendidikan SDM masjid Nahdliyyin ada empat poin yang menjadi konsen PC LTMNU Sidoarjo yakni:

a. Jalur Pendidikan

Pembinaan SDM takmir juga dilakukan dengan membina Lembaga Ta'mir Masjid Majelis Wakil Cabang (MWC) NU di tingkat kecamatan. Pembinaan dan pendidikan melalui jalur ini dilakukan dengan cara turun ke bawah (turba) dan rapat koordinasi. Secara insidental LTMNU Sidoarjo juga menyelenggarakan kajian keilmuan untuk warga Nahdliyyin secara umum termasuk para pengelola masjid.

b. Metode Pendidikan

Peserta didik untuk program pendidikan dan latihan (diklat) tidak hanya berasal dari Sidoarjo. Pada beberapa kali diklat terdapat peserta dari kabupaten sekitar Sidoarjo yakni Surabaya, Mojokerto dan Pasuruan meskipun persentasenya kecil. Peserta didik untuk metode dua dan tiga tidak ada pembatasan berdasarkan keriteria tertentu. Bahkan yang tidak bersinggungan dengan masjid boleh mengikutinya. Berbeda halnya dengan diklat, ada persyaratan tertentu yang harus dipenuhi. Umumnya persyaratan itu adalah mengisi formulir pendaftaran dan bersedia mengikuti seluruh sesi acara. Untuk diklat khothib, imam dan bilal serta muadzin disyaratkan kemampuan baca tulis Al-Qur'an. Tiga model pembinaan yang ada yaitu: (1) Pendidikan dan latihan (diklat) yang meliputi: diklat manajemen masjid, diklat bilal dan muadzin. Diklat imam dan makmum (sholat 
sempurna) dan diklat khothib. Peserta didiknya terdiri dari para imam, muadzin, bilal dan khothib masjid dan masholla Nahdliyyin; (2) Kajian umum tematik pesertanya adalah umat Nahdliyyin pada umumnya; dan (3) Konsultasi langsung, pesertanya adalah pengelola masjid yang menghadapi masalah. Peserta didik atau yang berkonsultasi bisa takmir masjid, imam masjid, atau yang lain.

c. Output Pendidikan

Setiap diklat yang dilakukan PC LTMNU Sidoarjo disertai dengan evaluasi. Evaluasi dilakukan untuk mengetahui daya serap materi oleh peserta. Pada saat tertentu, evaluasi juga digunakan untuk menentukan lulus tidaknya peserta diklat. Bagi peserta yang dinyatakan lulus akan mendapatkan sertifikat tanda kelulusan. Sedangkan yang tidak lulus akan mendapatkan sertifikat tanda keikutsertaan. Evaluasi dilakukan terkait dengan penguasaan materi juga dilakukan terhadap keaktifan peserta dan kesungguhan peserta dalam mengikuti seluruh sesi diklat. Evaluasi dilakukan pada saat berakhirnya diklat. Hasil evaluasi kemudian disampaikan langsung kepada peserta agar menjadi bahan meningkatkan kualitas diri setelah acara diklat. Untuk kajian tematik dan konsultasi tidak diagendakan evaluasi secara terprogram. Evaluasi diserahkan pada masing-masing peserta didik.

d. Ruang Lingkup Pendidikan

Pembinaan SDM pengelola masjid nahdliyyin juga sering dilakukan dengan konsultasi langsung. Dari buku tamu PC LTMNU Sidoarjo diketahui ada 76 kali forum konsultasi takmir masjid nahdliyyin dengan PC LTMNU Sidoarjo. Topik yang dikonsultasikan sangat beragam antara lain: (1) Mencari khothib Jum'at, Idul Fitri, Idul Adha; (2) status hukum tanah; (3) Pergantian pengurus; (4) Pembinaan imam dan jamaah; (5) Perebutan model ibadah; (6) Pendirian lembaga pendidikan; (7) Permohonan SK dan pelantikan; (8) Format acara dan narasumber acara PHBI; (9) Pengajuan permohonan bantuan rehabilitasi masjid; (10) Permohonan pembinaan manajemen masjid.

Model pembinaan semacam ini sangat efektif karena lingkup masalah dan subjek yang mengalaminya sangat terbatas sehingga solusi bisa bersifat spesifik dan kasuistik. Sebagai contoh konsultasi takmir Masjid Al-Hidayah Celep tentang amaliyah kirim Fatihah terhadap ahli kubur jamaah yang berinfaq. Amaliyah yang mentradisi tersebut mendapat tentangan justru dari Pengurus Ranting NU Celep. Bahkan ketika konflik makin tajam Pengurus Ranting yang merasa mengeluarkan SK pengesahan takmir mengancam akan mencabut SK tersebut. Solusi yang diberikan adalah dengan menerbitkan SK PC LTMNU tentang pengesahan takmir Masjid Al-Hidayah Celep. Setelah mengetahui bahwa Pengurus Ranting NU Celep tidak ber-SK, disarankan agar mengurus SK Pengurus Ranting NU Celep kepada Pengurus Cabang NU Sidoarjo. Konsultasi ini berlanjut dengan diadakannya pengajian rutin di Masjid Al-Hidayah.

Muatan Pendidikan SDM masjid Nahdliyyin ada empat poin yang menjadi konsen PC LTMNU Sidoarjo yakni: 
a. Bidang Manajemen Masjid

Diklat manajemen membutuhkan waktu 8 jam dengan alokasi waktu $40 \%$ praktik dan $60 \%$ teori. Praktik yang dilakukan meliputi: praktik menyusun program kerja, praktik memimpin rapat dan presentasi hasil rapat takmir. Paparan teori lainnya membutuhkan praktik langsung di masjidnya masing-masing. Materi pendidikan dan pelatihan manajemen masjid meliputi: 1) Pengenalan LTMNU, 2) Kepemimpinan takmir masjid, 3) Struktur organisasi dan pembagian tugas, 4) Penyusunan program kerja, 5) Manajemen keuangan, 6) Pedoman akuntansi sederhana, dan 7) Perwakafan.

b. Bidang Imam dan Jamaah Masjid

Pelatihan ini biasa disebut dengan pelatihan sholat sempurna. Muatannya lebih banyak praktik. Perbandingannya 40:60 untuk perbandingan teori dan praktiknya. Muatan pelatihan meliputi:1) Syarat rukun sholat dan thoharoh, 2) Sunnah-sunnah sholat, 3) Kesempurnaan gerakan dan bacaan, 4) Aturan sholat jamaah, dan Problematika sholat secara umum. Sedangkan praktik yang dilakukan meliputi:1) Talaqqi Al-Qur'an, tahiyat, qunut dan bacaan sholat sunnah yang lain, 2) Praktik menjadi imam, 3) Praktik menjadi makmum, 4) Praktik menilai sholat orang lain. Muatan/ materi yang cukup banyak membutuhkan waktu antara 16-24 jam yang bisa ditempuh dalam empat kali pertemuan atau dua hari pelatihan.

c. Bidang Khothib dan Da'i

Diklat ini merupakan yang paling berat dan syarat dengan materi. Diklat khothib mencakup materi diklat bilal dan diklat sholat sempurna baik praktik maupun teorinya. Di luar itu ada penambahan materi yaitu: 1) Syarat rukun khotbah, 2) Adab khotbah, 3) Problematika sholat Jum'at dan khotbah Jum'at, 4) Teknik penyusunan naskah khotbah mulai pemilihan topik, sistematika, hingga pemilihan kata dan kalimat dalam naskah khotbah, dan 5) Teknik penyampaian khotbah.

d. Bidang Bilal dan Muadzdzin

Praktik meliputi: pelafalan lafadz bilal dan adzan, praktik pelafalan dengan berdiri memegang tongkat, dan praktik menilai penampilan bilal. Setiap peserta dibekali cara menilai penampilan bilal dengan menunjukkan titik mana yang perlu diperhatikan dan bagaimana cara menilainya. Biasanya kegiatan pembinaan bilal dilakukan dalam bentuk workshop (pelatihan). Teori yang disampaikan hanya $25 \%$. Sisa digunakan untuk praktik dan evaluasi. Praktik dilakukan minimal dua kali bahkan bisa lebih untuk mengetahui tingkat perkembangan peserta. Materi yang berikan meliputi: 1) Pengertian, dasar hukum dan tugas bilal, 2) Lafadz bilal dan hukum bacaan yang terkait, 3) Penguasaan psikologi massa, dan 4) Problematika ibadah Jum'at secara umum.

Implementasi pendidikan SDM masjid-masjid Nahdliyyin dalam perjalanannya bisa diindikasikan ada beberapa faktor pendukung dan penghambat yang mewarnai pelaksanaan program tersebut. Belum tentu juga pendukung ini memberikan percepatan program dan belum tentu penghambat mebuat program terbengkalai, berikut ini faktor 
pendukung, antara lain: 1) Semangat para pengurus, 2) Kesamaan visi para pengurus, 3) Dorongan kyai-kyai, 4) Tempat yang strategis, 5) Saling pengertian.

Adapun faktor penghambat pada implementasi pendidikan SDM masjid - masjid Nahdliyyin, yakni: 1) Komitmen yang kadang kendor, 2) Tidak tepat waktu, 3) pendanaan yang minim, dan 4) efektitas kinerja kurang. Dengan dinamika yang kompleks, membuktikan NU melalui salah satu organnnya yakni LTMNU Sidoarjo mampu memberikan sumbangsih nyata pada masyarakat.

\section{Simpulan}

PC LTMNU mampu mengimplementasikan pendidikan SDM pengelola masjid Nahdliyyin mengacu pada keputusan organisasi dengan dinamika yang kompleks. Pendidikan dilaksanakan dalam tiga bentuk yakni diklat, kajian umum tematik dan konsultasi langsung. Diklat yang dilaksanakan merupakan bentuk dari pendidikan berbasis masyarakat yang berangkat dari kebutuhan masyarakat, dilakukan oleh masyarakat dan dengan kemampuan masyarakat. Diklat meliputi khothib, imam, muadzin, bilal dan manajemen takmir masjid.

\section{Referensi}

Aceh, AA. (1955). Sejarah Masjid dan Amal Ibadah di Dalamnya. Banjarmasin: Toko Buku Adi.

Ahmadi, R. (2005). Memahami Metodologi Penelitian Kualitatif. Malang: UM Press.

Arifin, I. (2010). Kepemimpinan Kiyai dalam Perubahan Manajemen Pesantren Kasus Pesantren Tebuireng. Yogyakarta: Aditya Media.

Badan Kesejateraan Masjid. (1996). Pola Pembinaan Kegiatan Kemasjidan, Jakarta: Proyek Peningkatan Sarana Keagamaan Islam, Zakat, dan Wakaf Departemen Agama RI.

Danim, S. (2002). Menjadi Peneliti kualitatif. Bandung, Pustaka Setia.

Komar, O. (2006) Filsafat Pendidikan Non Formal. Bandung: Pustaka Setia.

Mas'udi, MF. (2007). Membangun NU berbasis Masjid dan Umat, Jakarta: LTMI NU \& P3M.

Ruslan, H. (2010). Menelisik Warisan Peradaban Islam Dari Apotik Hingga Komputer Analog. Bandung : Penerbit Republika.

Sarijo, M. (1998). Bunga Rampai Pendidikan Islam. Jakarta: CV Amisco.

Shihab, Q. (2009). Tafsir Al-Misbah Pesan, Kesan dan keserasian Al-Qur'an Volume 5 Jakarta: Lentera Hati.

Staruss, A., Corbin, J. (2009). Dasar-Dasar Penelitian Kualitatif. Yogyakarta: Pustaka Pelajar.

Suhartono, S. (2008). Wawasan Pendidikan. Sleman: Ar-Ruz Media Group.

Suwito, Fauzan. (2005). Sejarah Sosial Pendidikan Islam. Jakarta: Kencana.

Tim Redaksi Nuansa Aula. (2005). Himpunan Perundang-undangan RI tentang Sistem Pendidikan Nasional. Bandung: Nuansa Aulia. 